\title{
EURYCOMA LONGIFOLIA, A MALAYSIAN MEDICINAL HERB, SIGNIFICANTLY UPREGULATES PROLIFERATION AND DIFFERENTIATION IN PRE-OSTEOBLASTS (MC3T3-E1): AN IN VITRO MODEL
}

\author{
HNIN EI THU1, ISA NAINA MOHAMED ${ }^{1}$, ZAHID HUSSAIN ${ }^{2}$, NORAZLINA MOHAMED1, AHMAD NAZRUN SHUID1* \\ ${ }^{1}$ Department of Pharmacology, Faculty of Medicine, Universiti Kebangsaan Malaysia (The National University of Malaysia), Jalan Yaacob \\ Latif 56000, Cheras, Malaysia, ${ }^{2}$ Department of Pharmaceutics, Faculty of Pharmacy, Universiti Teknologi MARA, Puncak Alam Campus, \\ Bandar Puncak Alam 42300, Selangor, Malaysia \\ Email: anazrun@yahoo.com
}

Received: 06 Aug 2016 Revised and Accepted: 09 Sep 2016

\section{ABSTRACT}

Objective: Eurycoma longifolia (EL), a well-recognized Malaysian medicinal herb, has gained widespread popularity due to its ability to protect against bone calcium loss in androgen-deficient osteoporosis. Nevertheless numerous animal studies have proved the bone protective effect of $E L$; however, the exact mechanism is not well-explained yet. Thus, the present study was aimed to explore the in vitro basis of bone protective effects of EL by using mouse pre-osteoblast cell line (MC3T3-E1).

Methods: The cytotoxicity and proliferative potential of $E L$ were evaluated by lactate dehydrogenase (LDH) and cell counting methods. Despite cell growth, the ability of $E L$ to promote osteogenic differentiation of bone-forming cells was assessed by quantifying collagen (early differentiation marker) and calcium (late differentiation marker) in $E L$-treated bone forming cells.

Results: Resulting data obtained from dose optimization study revealed that $E L$ at 5 to $50 \mu \mathrm{g} / \mathrm{ml}$ concentration showed marked effects in significantly promoting cell growth in MC3T3-E1 cells. As such, resulting data also demonstrated the superior potential of $E L$ in up regulating collagen synthesis and mineralization (calcium deposition) in MC3T3-E1 cells at $25 \mu \mathrm{g} / \mathrm{ml}$, in comparison to untreated (negative control) and dihydrotestosterone ( $5 \alpha$-DHT)-treated cells (positive control).

Conclusion: These pronounced effects of $E L$ on osteoblasts provide an in vitro basis for the bone protective potential of $E L$ and thus can be considered as an alternative regimen for the treatment of androgen-deficient male osteoporosis.

Keywords: Eurycoma longifolia, Androgen-deficient osteoporosis, $5 \alpha$-dihydrotestosterone, Cell proliferation, Collagen deposition, Mineralization

(C) 2016 The Authors. Published by Innovare Academic Sciences Pvt Ltd. This is an open access article under the CC BY license (http://creativecommons.org/licenses/by/4. 0/) DOI: http://dx.doi.org/10.22159/ijpps.2016v8i11.14518

\section{INTRODUCTION}

Osteoporosis is one of the most prevalent bone diseases resulting from an overwhelming imbalance in bone remodeling. It is characterized by an excessive bone resorption by osteoclasts relative to the bone formation by osteoblasts [1-3]. Like all metabolically active cells, osteoblasts and osteoclasts require endocrine player i.e. hormonal guidance to execute their metabolic activities [4]. Osteoblasts are primarily regulated by progesterone and testosterone, while osteoclasts require estrogen-like hormones to exert their functional roles. It is well-established that sex hormones (estrogen, progesterone and androgen) are among the crucial modulators of bone health, particularly in protecting bones from weakness and regulating bone minerals to optimum levels [5-7]. Testosterone and dihydrotestosterone ( $5 \alpha$-DHT) are well-recognized androgens to promote proliferation and differentiation of osteoblasts [8-10]. An imbalance in the homeostasis of these hormones may cause rapid bone deterioration due to lack of functioning osteoblasts and osteoclasts [5]. The unbalanced cellular activity which could result in the intermittent bone formation and resorption is most commonly associated with the development of metabolic bone disorders (including osteoporosis) and related bone fractures $[2,11]$

Generally, pharmacological therapies used to treat androgendeficient osteoporosis are categorized as anti-resorptive agents, that inhibit osteoclastic bone resorption, and anabolic agents, that stimulate osteoblastic bone formation. Several antiresorptive agents such as bisphosphonates (BPH), selective androgen receptor modulators (SARM), hormone replacement therapy (HRT) and calcitonin are well-recommended agents for the treatment of osteoporosis [12]. However, due to multiple side effects associated with the use of SARMs, BPH, HRT, and calcitonin, the clinical applicability of these agents has been abridged [13]. Due to these potential risks and compromised patient compliance, the healthcare professionals and research experts are always in search of natural herbal products as alternative therapies for the treatment of male osteoporosis and other bone related disorders.

Eurycoma longifolia (EL), in the family of Simaroubaceae, also known as Tongkat Ali or Malaysian ginseng, is a potent medicinal herb that is well-recognised in stimulating the production of testosterone. It is predisposed to be used as a potential therapeutic alternative to HRT for the treatment of androgen deficiency male osteoporosis [10]. Due to high demand and tremendous health benefits, EL preparations are now widely available in the health-food market in the form of energy drinks, sexual health improving capsules, and nutritional extracts [9, 13-16]. A recent study has demonstrated the potential of EL in promoting bone formation and diminishing bone resorption [17]. EL extract elevated testosterone levels in orchidectomies rats and abolished bone resorption as shown by down-regulation of bone resorption marker and up-regulation of osteoprotegerin (OPG) gene expression [17]. However, the in vitro basis and the exact mechanism of EL in treating male osteoporosis were still debatable.

The present study aimed to explore the in vitro proliferative and osteogenic effects of $E L$ using MC3T3-E1 cells. The results were compared with negative control (untreated) and positive control (treated with $5 \alpha$-DHT) groups. The cytotoxic and proliferative potential of $E L$ was analyzed using LDH cytotoxicity assay and cell counting method. The differentiation activity of $E L$ was assessed by evaluating collagen synthesis and matrix mineralization (calcium deposition) in bone forming cells. The resulting data demonstrated that $E L$ showed greater potential in promoting proliferation, differentiation and mineralization in osteoblasts and thus can be considered as a promising alternative anti-osteoporotic therapy. 


\section{MATERIALS AND METHODS}

\section{Materials}

Mouse calvariae origin osteoblastic cell line (MC3T3-E1) subclone 14 (CRL-2594, highly differentiating osteoblast) purchased from american type culture collection (ATCC) cell bank (Manassas, VA, USA) was used as in vitro model. Cell culture reagents (Alpha modified minimal essential medium ( $\alpha$-MEM), penicillin and streptomycin and fetal bovine serum (FBS)) were sourced from Gibco Laboratories (Grand Island, NY, USA). Ascorbic acid and $\beta$ glycerophosphate were purchased from Sigma-Aldrich, USA. LDH (lactase dehydrogenase) assay kit was purchased from Cayman chemicals (601170) (Ann Arbor, MI, USA). For qualitative and quantitative measurement of collagen, sirius red/fast green collagen staining kit along with kahle fixative buffer was purchased from AMSBIO (9046) (UK). Eurycoma longifolia Jack (EL) was sourced from the faculty of pharmacy (University Sains Malaysia, Malaysia). The composition of the extract was same as that used in health supplements. $5 \alpha$-Dihydrotestosterone ( $5 \alpha$-DHT) was purchased from Sigma-Aldrich (Germany). All other chemicals used were obtained from pharmacology and cell culture laboratories of Universiti Kebangsaan Malaysia, Malaysia.

\section{Cell culture}

Mouse MC3T3-E1 pre-osteoblasts were routinely cultured in a growth medium consisting of $\alpha$-MEM supplemented with $10 \%$ heatinactivated FCS and 1\% penicillin/streptomycin (Antibiotic/ Antimycotic). The cells were then incubated in humidified chamber $\left(95 \%\right.$ air and $\left.5 \% \mathrm{CO}_{2}\right)$ at $37{ }^{\circ} \mathrm{C}$ until they reached $80 \%$ confluence. The adherent cells were then enzymatically released from the flask by treating with an aqueous solution of $0.2 \%$ trypsin and $0.02 \%$ EDTA (ethylenediamine tetraacetic acid) for 2-4 min.

The cells were counted using a hemocytometer and seeded at a density of $1 \times 10^{3} \mathrm{cells} / \mathrm{cm}^{2}$ in 96 -wellplate and were then cultured under the same above experimental conditions. For experiments, cells were cultured for $24 \mathrm{~h}$ to obtain monolayers containing $\alpha$-MEM with $10 \%$ FCS to promote cell survival, division, and metabolism. Prior to initiating osteogenic differentiation, cells were sparsely seeded into 96-well culture plates and were cultured in an incubator overnight. For the cell differentiation experiment, MC3T3-E1 cells were cultured in an osteogenic differentiation medium which contains regular media described above plus $50 \mu \mathrm{g} / \mathrm{l}$ ascorbate analog that resists hydrolysis (ascorbate-2-phosphate) to permit collagen type I fibril assembly and $10 \mathrm{mmol} \beta$-glycerophosphate to promote mineralization of collagen fibrils. During the pre-determined experimental period, cultured cells were typically fed twice weekly over a 2 to 3 -week period with an osteogenic differentiation medium.

\section{Drug treatment}

Prior to further screening or treatment, a stock solution of $E L$ was prepared at the final concentration of $25 \mathrm{mg} / 10 \mathrm{ml}$ using either $\alpha$ MEM or differentiation media. Various concentrations of $E L$ were then prepared from stock solution and were sterilized with a filtration process using a syringe filter $(0.2 \mu \mathrm{m}$, Sartorius, Germany). Following that, MC3T3 cells were treated with different concentrations (1-100 $\mu \mathrm{g} / \mathrm{ml})$ of $E L$ and culture media was replaced every three days throughout the experimental period.

\section{Cell cytotoxicity assay}

\section{Lactate dehydrogenase (LDH) activity}

In an attempt to select a safe and effective dose of EL, cells toxicity was determined by incubating MC3T3-E1 cells with different concentrations of EL at time point; after $24 \mathrm{~h}$ (day-1), using LDH assay kit. The amount of LDH released from dead or dying cells into the culture medium was measured with a colorimetric method following the manufacturer's protocol. This colorimetric assay quantifies the activity of LDH released from the cytosol of damaged cells into the supernatant and thus serves as an index of cell death. The values of LDH were determined by a coupled enzymatic assay that utilizes the conversion of a tetrazolium salt into a brightly colored formazan product which has a maximum absorbance of $490 \mathrm{~nm}$.
Briefly, MC3T3-E1 cells were seeded at a density of $1 \times 10^{3}$ cells/well in 96-well culture plates and maintained in growth media for $24 \mathrm{~h}$ at $5 \% \mathrm{CO}_{2}$ at $37^{\circ} \mathrm{C}$. At the end of incubation, the media was replaced with fresh growth medium containing different concentrations of $E L$ $(1-100 \mu \mathrm{g} / \mathrm{ml}$ ) for $16 \mathrm{~d}$. The growth media (without $E L$ ) was used as negative control (NC) while $5 \alpha$-DHT at $100 \mathrm{pg} / \mathrm{ml}$ concentration was used as positive control (PC). After specified exposure period, $100 \mu \mathrm{l}$ culture media was collected from each set of MC3T3-E1 cells to test for cytotoxicity (LDH activity). The collected culture media was transferred into a new 96 well plates pre-filled with $100 \mu \mathrm{l}$ of the reaction solution and incubated at room temperature for 30 min using an orbital shaker. The absorbance of each well was recorded using microplate reader for colorimetric detection. Blank culture medium was used as a background control. The experiment was performed in triplicates. Results were presented relative to LDH activity in the media of NC cells $(100 \%$ of cell viability) and of cells treated with $1 \%$ Triton X-100 ( $0 \%$ cell viability) using the equation 1 :

$$
\text { Cell viability }(\%)=\frac{\text { EL/DHT treated cells }-\mathrm{NC} \text { cells }}{\text { Triton }- \text { treated cells }-\mathrm{NC} \text { cells }} \times 100
$$

\section{Cell count}

For cell proliferation assay, MC3T3-E1 cells were plated in 12-well plates at an initial cell density of $1.5 \times 10^{5}$ cells/well. Cells were treated with various concentrations $(5,25,50$ and $100 \mu \mathrm{g} / \mathrm{ml})$ of $E L$. At predetermined time points (Day-1, Day- 3 and Day- 6 of culture), cells were isolated and detached by adding trypsin to the cells and incubating them to remove the cells from the surface of the culture plates. Then, the detached cells were centrifuged, re-suspended in media and cell number was counted in a hemocytometer using trypan blue dye exclusion test. The experiments were repeated three times (each with triplicate samples).

\section{Assessment of cell differentiation \\ Synthesis and deposition of collagen}

The effect of $E L$ on the differentiation of MC3T3-E1 cells was also assessed at various time intervals $(3,6,9,15$, and $21 \mathrm{~d})$ by evaluating the propensity of ECM collagen synthesis compared to the control cells. In this experiment, the cellular matrix was stained using Sirius red/fast green staining kit according to the manufacturer's protocol. Briefly, the treated cells seeded in 96-wells culture plate were washed with PBS thrice and were then fixed with kahle fixative solution for 10 min at room temperature. The treated and washed cells were then incubated with sirius red/fast green stain for $30 \mathrm{~min}$ at room temperature and were rinsed with deionized water repeatedly until the fluid was colorless. Following that, the stained cells were observed and photographed under inverted phase contrast microscope attached with a digital camera (Leica, Tokyo). A dye extraction buffer was then added to the stained wells and gently mixed by pipetting until the color was eluted from the cells. The eluted dye solution was collected, and the optimal density (OD) values were recorded at $540 \mathrm{~nm}$ and 605 nm using a spectrophotometer.

\section{Synthesis and deposition of calcium minerals}

Mineralization of bone forming cells is an important event to assess the differentiation potential of a test compound on MC3T3-E1 cells. Hence in this experiment, the degree of mineralization of treated cells was evaluated throughout the experimental period of $21 \mathrm{~d}$ in comparison to the control cells. Briefly, $1 \times 10^{5}$ cells/well were seeded in 24-wells culture plates and induced with osteoblast differentiation medium. Prior to staining, the cells were treated with different concentrations of $E L(5,25$ and $50 \mu \mathrm{g} / \mathrm{ml})$ or $5 \alpha$-DHT (100 $\mathrm{pg} / \mathrm{ml}$ ) as a positive control or left untreated (CN) throughout the differentiation phase, and the medium was changed every alternate day. At each pre-specified time, the media was removed, and the cells were washed with PBS thrice, fixed with $4 \%$ paraformaldehyde for $20 \mathrm{~min}$ at $4{ }^{\circ} \mathrm{C}$ and subsequently were rinsed with deionized water. Finally, the fixed cells were stained with $40 \mathrm{mmol}$ alizarin reds (ARS) solution ( $\mathrm{pH} \mathrm{4.4)}$ for 30 min at room temperature with gentle shaking. To quantify the bound dye, the stain was solubilized with 10 percent cetyl pyridinium chloride while continuously shaking. The absorbance was recorded at $562 \mathrm{~nm}$. 


\section{Statistical data analysis}

All the experiments were performed independently three times (each with triplicate samples; $\mathrm{n}=9$ ) and the resulted data were expressed as mean \pm standard deviation (SD) One-way analysis of variance (one-way ANOVA) followed by Duncan's multiple new range tests was performed using SPSS version 21.0. Statistical significance between tested groups was assigned as ${ }^{*} p<0.05$.

\section{RESULTS AND DISCUSSION}

\section{Effect of $E L$ on MC3T3-E1 cells cytotoxicity}

The purpose of this preliminary study was to assess the undesirable cytotoxic effects of $E L$ on MC3T3-E1 cells. Cell viability and plasma membrane integrity were tested during LDH release assay. The results obtained were presented in fig. 1 . The resulting data demonstrated that both the CN and DHT-treated MC3T3-E1 cells showed $100 \%$ viability during the $24 \mathrm{~h}$ incubation period under physiological condition. Similarly, the MC3T3-E1 cells treated with $E L$, particularly at lower concentrations $(1-50 \mu \mathrm{g} / \mathrm{ml})$, showed $100 \%$ viability; however, a further increase in the concentration of $E L(>50 \mu \mathrm{g} / \mathrm{ml})$ produced a sign of toxicity towards MC3T3-E1 cells (fig. 1). Data analysis showed that at a concentration of $100 \mathrm{ug} / \mathrm{ml}$ of $E L$, cell viability was $90 \%$. Further increase in the concentration of $E L(>50 \mu \mathrm{g} / \mathrm{ml})$ is not safe and may cause cytotoxic effects and is not appropriate for prolonged cell culture. To harmonize the concentration-dependent effects of $E L$, four concentrations (5, 25, 50 and $100 \mu \mathrm{g} / \mathrm{ml}$ ) were chosen for further screening.

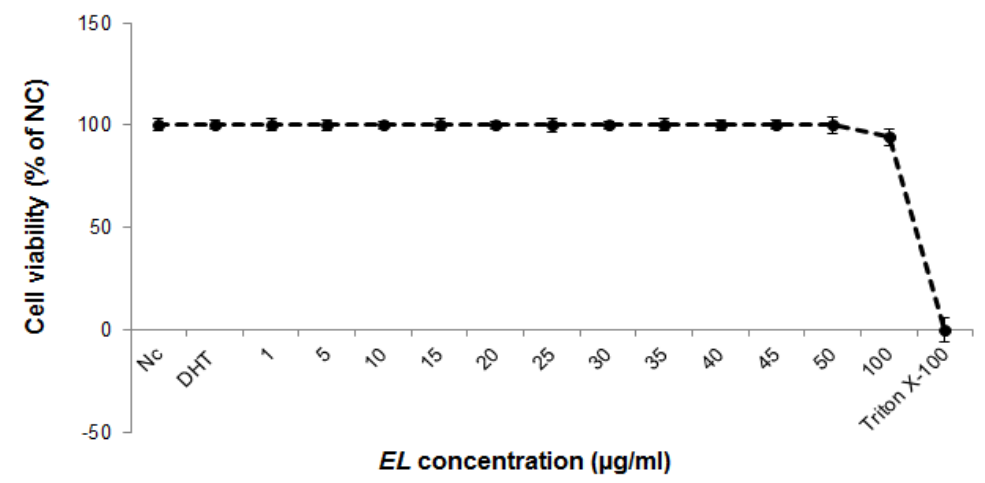

Fig. 1: Cell viability of MC3T3-E1 cells after $24 \mathrm{~h}$ exposure with $E L$, in comparison to DHT-treated and untreated (NC) MC3T3-E1 cells. Cell viability was determined by measuring LDH activity. Results were presented relative to the LDH activity in the media of untreated (NC) cells (100\% of cell viability) and of cells treated with $1 \%$ Triton $X-100(0 \%$ cell viability) using the equation 1 . The results were reported as mean $\pm S D(n=9)$

\section{Effect of $E L$ on MC3T3-E1 cells count}

In this experiment, the growth rate of MC3T3-E1 cells treated with different concentrations of $E L(5,25,50$ and $100 \mu \mathrm{g} / \mathrm{ml})$ or $5 \alpha$-DHT was recorded in comparison to the $\mathrm{NC}$ at various time points $(1,3$ and 6 d) (fig. 2). The resulting data demonstrated that the cell number gradually increased with time in all (untreated and treated) groups. The untreated and treated cells showed a growth curve characteristic of MC3T3-E1 pre-osteoblastic cells, with the numbers doubling each day to form an exponential growth trend (fig. 2). MC3T3-E1 cells treated with $5 \alpha$-DHT showed significantly higher proliferation than negative control $(\mathrm{NC})$ group at day- $1(p<0.05)$; and exhibited consistent proliferation at day-3 and day-6 (fig. 2). This indicated greater cell proliferating potential of $5 \alpha$-DHT compared to the NC group. The number of MC3T3-E1 cells treated with selected concentrations of $E L(5,25,50$ and $100 \mu \mathrm{g} / \mathrm{ml})$ was not significantly different compared to the NC group at day- $1(p>0.05)$. However, the rate of proliferation was significant than the NC group at day-3 to day- 6 (predominantly in cells treated with 5 and 25 $\mu \mathrm{g} / \mathrm{ml})(p<0.05)$. The rate of cell growth was decreased when the concentration of $E L$ was increased to 50 and $100 \mu \mathrm{g} / \mathrm{ml}$ (fig. 2). Therefore, higher concentrations of $E L$ might cause cell apoptosis as supported by the LDH-based cell cytotoxicity assay data (fig. 1). The quantitative analysis provided further evidence for the cell proliferating ability of $E L$ ( 5 and $25 \mu \mathrm{g} / \mathrm{ml}$ ). There was no significant difference with $5 \alpha$-DHT, but the proliferation rate for $E L$ became significant compared to NC only at day-3 and day-6. Based on these results, it was predicted that higher concentration of $E L(>50 \mu \mathrm{g} / \mathrm{ml})$ adversely affected the viability and growth rate of MC3T3-E1 cells and thus was excluded from further screening and cell culturing. Low doses of $E L(5,25$ and $50 \mu \mathrm{g} / \mathrm{ml})$ were chosen for further evaluation of its differentiation potential on bone forming cells.

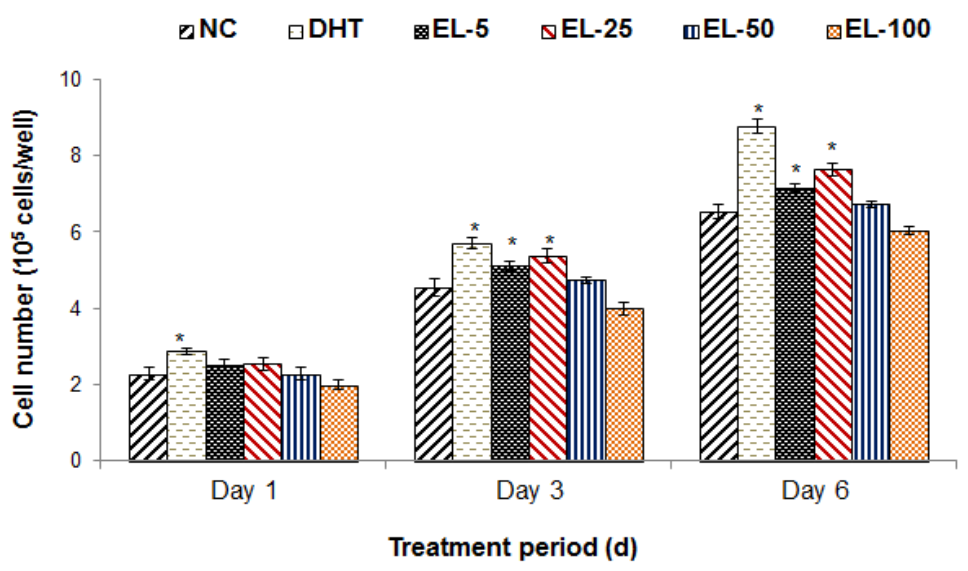

Fig. 2: Proliferation of MC3T3-E1 cells treated with various concentrations of $E L(5,25,50$ and $100 \mu \mathrm{g} / \mathrm{ml})$, in comparison to untreated (NC) and DHT-treated (dihydrotestosterone) groups measured by direct cell counting. Each bar denotes mean \pm SD from three experiments, each with triplicate samples $(n=9)$, *indicates significant difference $(p<0.05)$ between untreated $(\mathrm{NC})$ and treated cells 


\section{Effect of $E L$ on cell differentiation}

The osteoblastic phenotype differentiation during bone formation is acquired in two phases. The first or the early phases of differentiation is specified by the maturation of ECM and the relative expression of matrix proteins of bone cell phenotype which include

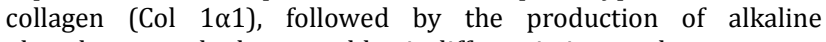
phosphatase and other osteoblastic differentiation markers.

In the second or late phase of differentiation, ECM turns mineralized by calcium deposition which results in the configuration of layers of spongy bone around the original cartilage [18]. In the later development phase, spaces among the spongy bone are filled with bone matrix and result in the formation of compact bone.

Thus in the present study, early differentiation markers which include collagen and the late markers of differentiation such as calcium mineralization of treated bone forming cells were examined to evaluate the effect of $E L$ on osteoblast differentiation.

\section{Expression of collagen}

In this study, sirius red/fast green staining kit was used to determine the degree and extent of collagen deposition of MC3T3-E1 cells [19]. In this study, the time-dependent modulation in collagen deposition was observed from day-3 to day-21 (fig. 3).

Histochemical analysis revealed that collagen deposition was not notably marked in both the controls and $E L$-treated groups until day- 6 as depicted by fig. 3 . The resulting monographs further revealed that the magnitude of collagen deposition was progressively increased in all the treated and untreated groups in a time-dependent manner from day-9 to day-21 and the collagen density was highest on day- 21 . Further analysis of the resulted monographs showed that noticeably higher integers of cellular and matrix collagen were observed in MC3T3-E1 cells treated with EL-25 compared to other $E L$-treated groups $(5$ and $50 \mu \mathrm{g} / \mathrm{ml})$ and $\mathrm{NC}$ group. Moreover, cells treated with $E L-25$ also showed promisingly higher intensity of collagen deposition compared to those treated with $5 \alpha$-DHT (fig. 3).

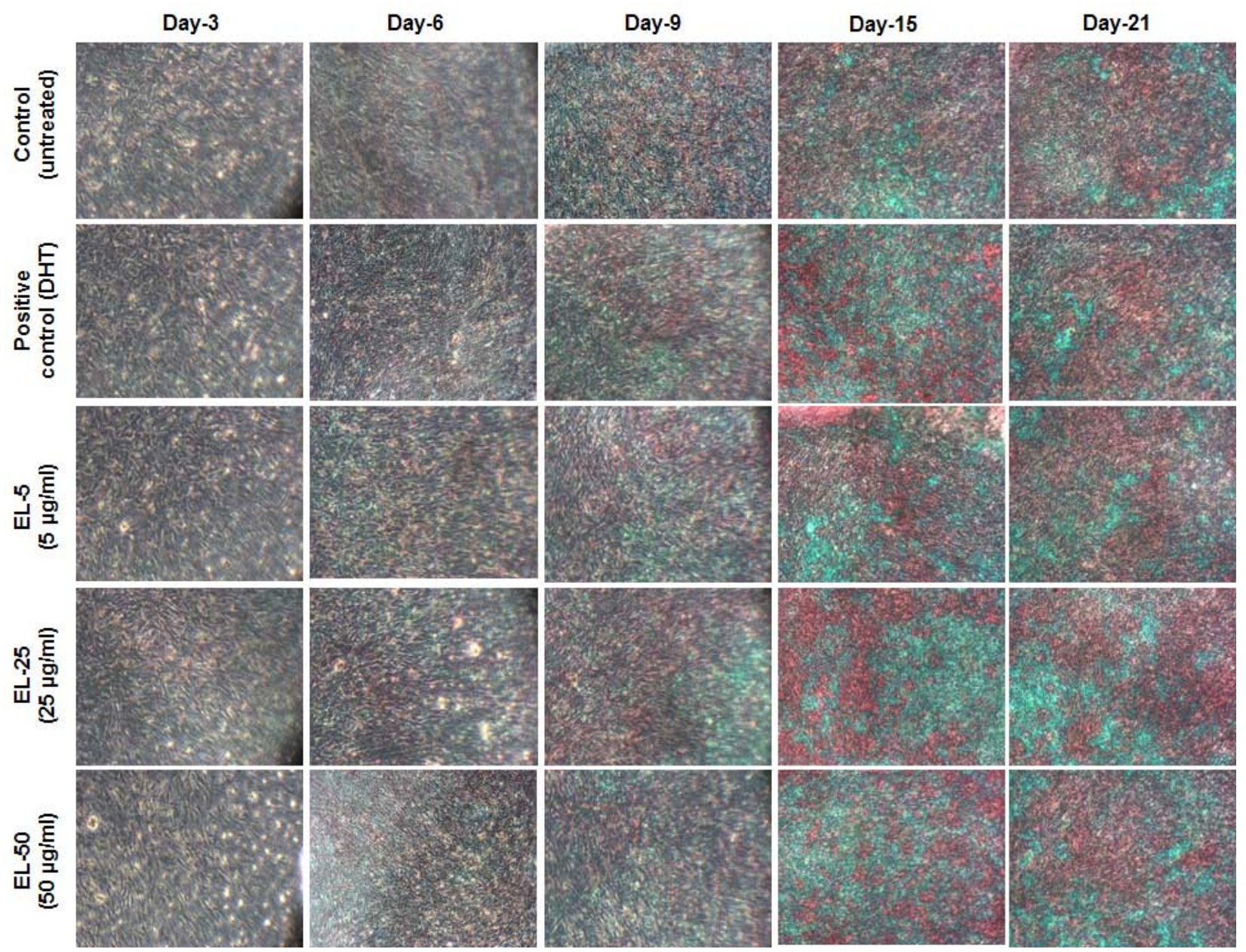

Fig. 3: Collagen staining of MC3T3-E1 cells. Photomicrographs showed comparatively higher collagen deposition in EL-25 treated MC3T3E1 cells, in comparison to controls and other $E L$-treated concentrations at various time points. The photomicrographs were taken from four different regions of stained cells

Collagen deposition was also measured quantitatively and the results were shown in fig. 4. Quantitative analysis of the resulting data demonstrated a time-mannered increase in collagen accumulation in the cell and matrix layer of MC3T3-E1 cells treated with $E L$ and controls. As evaluated from the resulted data, collagen accumulation was relatively low until day-9 of culture (fig. 4). The increase in collagen deposition was more evident on day-15 in both the control and EL-treated cells. Data clearly identified that the accumulation of collagen was more pronounced in MC3T3-E1 cells treated with EL-25 compared to controls and other $E L$-treated cells (fig. 4). These results were in agreement of the data presented in fig. 3 (qualitative assessment of collagen expression) showing that the highest deposition of collagen was observed in MC3T3-E1 cells treated with $E L-25$ and the magnitude of accumulation was more pronounced on day-15. The relatively greater differentiation of MC3T3-E1 using $25 \mu \mathrm{g} / \mathrm{ml}$ of $E L$ further confirmed that $E L$ has accelerated effects on osteogenic differentiation of pre-osteoblasts. 


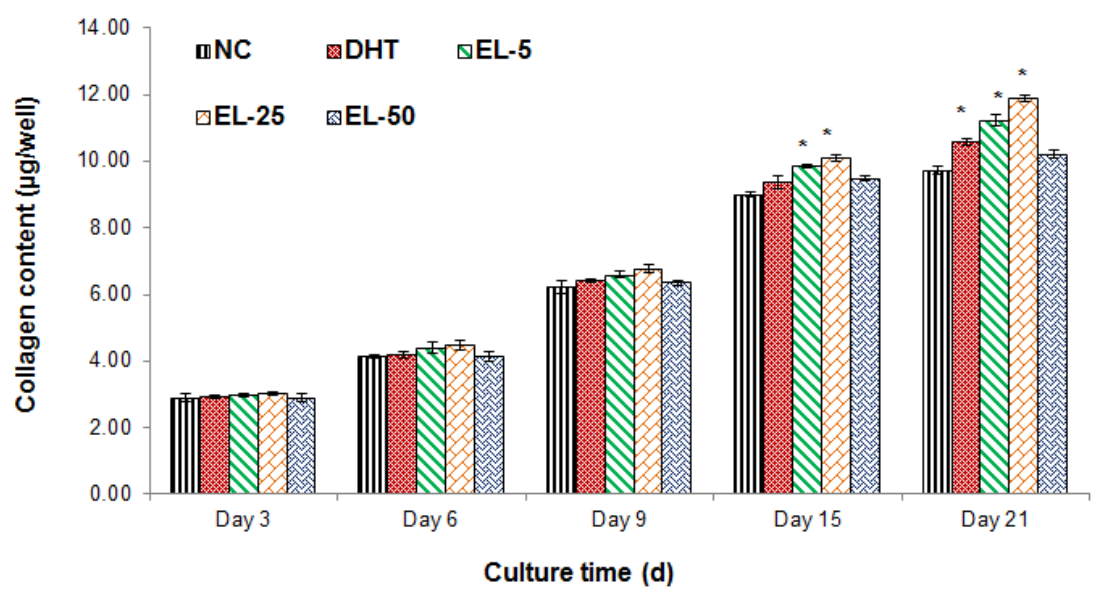

Fig. 4: The quantitative estimation of collagen deposition in the mineralized matrix was analyzed by Sirius red staining. MC3T3-E1 cells were induced with the osteogenic medium after treatment with 5, 25 and $50 \mu \mathrm{g} / \mathrm{ml} E L$ or DHT or untreated (NC) for 9, 15 and $21 \mathrm{~d}$. Data were expressed as means $\pm \operatorname{SD}(n=9)$. * indicated significant differences between untreated $(\mathrm{NC})$ and treated groups $(\mathrm{p}<0.05)$. EL: Eurycoma Longifolia; DHT: Dihydrotestosterone; NC: Untreated

Comparatively, higher intensity of collagen deposition entailed in $E L$-treated MC3T3-E1 cells clearly indicated the promising potential of $E L$ in stimulating osteoblast maturation and differentiation, the signs of bone matrix formation. It was reported that collagen matrix is induced osteoblastic differentiation which may be contributed by the interaction between collagen matrix and integrin receptors of cells [20]. Takeuchi and co-authors also reported that interaction of type I collagen with cell-surface $\alpha 2 \beta 1$ integrin receptors on MC3T3E1 cells is required for osteoblastic differentiation [21]. The present results were in accordance with previous studies which had reported that collagen was predominantly expressed in bone cells during osteoblast differentiation [22]. Time-dependent increased collagen production was expected to be due to the ascorbic acid which plays key role as a cofactor in the posttranslational modification of collagen molecules [23]. Looking further into the importance of collagen on bone mineralization, it was evident that silencing collagen could result in a reduction of both calcium and phosphate deposits [22, 23]. Collectively, another finding also demonstrated that collagen was not only selectively expressed in bone tissues, but it appears to have an integral role in osteoblast differentiation and the formation of the mineralized bone matrix [24].

\section{Assessment of mineralization: calcium deposition}

The effect of $E L$ on the differentiation of MC3T3-E1 cells in terms of cell matrix mineralization and calcium deposition was assessed quantitatively using ARS dye which characteristically reacts with calcium ions in mineralized deposits and appears as calcified nodules acquiring a bright red color (fig. 5). The resulting data indicated an increased calcium accumulation in the cell and matrix layer of MC3T3-E1 cells treated with both 5 $\alpha$-DHT and EL compared to NC group. Calcium deposition was more pronounced in $E L$ treated cells. Data clearly identified that MC3T3-E1 cells treated with $E L$ (particularly at the concentration $25 \mu \mathrm{g} / \mathrm{ml}$ ) showed the highest mineralization compared to those of controls (fig. 5).

Accumulation of calcium in the extracellular matrix (ECM) was detectable during the first $2 \mathrm{w}$ of culture in osteogenic media [25]. In this study, the presence of calcium in cellular deposits was confirmed by ARS staining with the application of cetyl pyridinium chloride for quantification. Similar to ECM maturation and the relative expression of bone cell-specific proteins (collagen), ECM mineralization is among the prime cellular differentiating parameter which indicates active bone formation. The calcium deposition is an ultimate phenotypic expression of osteogenesis and has been accepted as a marker for bone regeneration [26]. Moreover, ECM mineralization increases the anabolic activity in bone metabolism and also describes the final stages of osteoblastic differentiation at $21 \mathrm{~d}$. It was observed in this study that the cultured cells grown in the presence of $E L$ showed significant mineralization $(\mathrm{p}<0.05)$ compared to those of control groups. Notably, the calcium deposition was significantly higher in MC3T3-E1 cells treated with EL-25 compared to those of controls, $E L$ 5 or $E L-50$. A similar pattern was seen with the above-discussed collagen assessment, thereby confirming that $E L-25$ has shown tremendous efficiency to promote differentiation in MC3T3-E1 cells compared to those of controls or other $E L$-treated groups. These findings compiled that $25 \mu \mathrm{g} / \mathrm{ml}$ of $E L$ was the optimum dose in accelerating the late osteogenic differentiation in MC3T3-E1 cells.

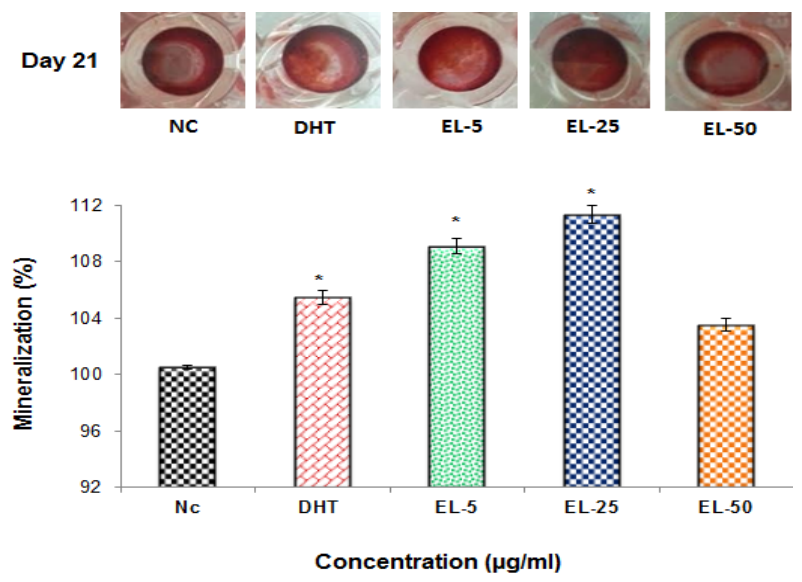

Fig. 5: Bone mineralization in terms of calcium deposition was evaluated using ARS staining. MC3T3-E1 cells induced with the osteogenic medium after treatment with 5,25 and $50 \mu \mathrm{g} / \mathrm{ml} E L$ or DHT or no treatment (NC) were analyzed on day 21. Results showed higher mineralization (calcium deposition) in MC3T3E1 cells treated with $25 \mu \mathrm{g} / \mathrm{ml}$ concentration of $E L$. Data was expressed as mean $\pm S D(n=9) .{ }^{*} p<0.05$ indicate a significant difference between untreated (NC) and treated cells. $E L$ : Eurycoma Longifolia; DHT: Dihydrotestosterone; NC: Untreated

\section{CONCLUSION}

In conclusion, this study has demonstrated for the first time that $E L$ promoted osteoblasts proliferation, osteoblast differentiation and mineralization of ECM. The optimum dose of EL to stimulate proliferation and differentiation of MC3T3-E1 cells was $25 \mu \mathrm{g} / \mathrm{ml}$. The ability of $E L$ to promote proliferation in bone forming cells was slightly less than $5 \alpha$-DHT; however its efficacy to promote cell differentiation was noticeably superior to the androgen hormone. Interestingly, the present study bridges the concept of $E L$ beneficial 
effects in promoting bone mass seen in previous animal studies. Taken together, EL significantly up-regulated differentiation in bone forming cells, as demonstrated by mineralized nodule formation and up-regulation of collagen in MC3T3-E1 cells. Thus, it is anticipated that $E L$ could be considered as an alternative approach to hormone replacement therapy (HRT) for the prevention and treatment of osteoporosis.

\section{ACKNOWLEDGEMENT}

Authors would like to acknowledge the Ministry of Agriculture for providing New Application for Herbal Research Grant Scheme (NRGS) (NH1014D040). The authors would also like to acknowledge the Department of Pharmacology, Faculty of Medicine, Universiti Kebangsaan Malaysia (UKM) for providing resources and tremendous support throughout the research process. We are grateful to Ms. Nurul Hafiza Abas from the Department of Pharmacology, Faculty of Medicine UKM, for her excellent and capable technical assistance.

\section{CONFLICT OF INTERESTS}

The authors report no conflict of interest in current research work

\section{REFERENCES}

1. Dennison E, Mohamed MA, Cooper C. Epidemiology of osteoporosis. Clin Rheum Dis 2006;32:617-29.

2. Lee YS, Choi EM. Costunolide stimulates the function of osteoblastic MC3T3-E1 cells. Int Immunopharmacol 2011;11:712-8.

3. Miao Q, Li JG, Miao S, Hu N, Zhang J, Zhang S, et al. The boneprotective effect of Genistein in the animal model of bilateral ovariectomy: roles of phytoestrogens and PTH/PTHR1 against postmenopausal osteoporosis. Int J Mol Sci 2012;13:56-70.

4. Leder BZ, LeBlanc KM, Schoenfeld DA, Eastell R, Finkelstein JS. Differential effects of androgens and estrogens on bone turnover in normal men. J Clin Endocrinol Metab 2003;88:204-10.

5. Raisz LG. Pathogenesis of osteoporosis: concepts, conflicts, and prospects. J Clin Invest 2005;115:3318-25.

6. Lips P. Vitamin D physiology. Prog Biophys Mol Biol 2006;92:4-8.

7. Kaunitz AM, Mcclung MR, Feldman RG. Post-menopausal osteoporosis: fracture risk and prevention. J Farm Pract 2009;58:S1-S6

8. Bland R. Steroid hormone receptor expression and action in bone. Clin Sci (Lond) 2000;98:217-40.

9. Compston JE. Sex steroids and bone. Physiol Rev 2001;81:419-47.

10. Favus MJ. Bisphosphonates for osteoporosis. N Engl J Med 2010;363:2027-35

11. Hou JM, Xue Y, Lin QM. Bovine lactoferrin improves bone mass and microstructure in ovariectomized rats via OPG/RANKL/RANK pathway. Acta Pharmacol Sin 2012;33:1277-84.

12. Jordan N, Barry M, Murphy E. Comparative effects of antiresorptive agents on bone mineral density and bone turnover in postmenopausal women. Clin Interventions Aging 2006;1:377-87.

13. Vanderschueren D, Vandenput L, Boonen S, Lindberg MK, Bouillon R, Ohlsson C. Androgens and bone. Endocr Rev 2004;25:389-425.
14. Ang HH, Cheang HS. Effects of Eurycoma longifolia Jack on laevator ani muscle in both uncastrated and testosteronestimulated castrated intact male rats. Arch Pharm Res 2001;24:437-40.

15. Malviya N, Jain S, Gupta VB, Vyas S. Recent studies on aphrodisiac herbs for the management of male sexual dysfunction-a review. Acta Pol Pharm 2011;68:3-8.

16. Varghese CP, Ambrose C, Jin SC, Lim YJ. Antioxidant and antiinflammatory activity of Eurycoma Longifolia Jack, a traditional medicinal plant in Malaysia. Int J Pharm Sci Nanotechnol 2012;5:1875-8

17. Shuid AN, El-arabi E, Effendy NM, Razak HS, Muhammad N, Mohamed N, et al. Eurycoma longifolia upregulates osteoprotegerin gene expression in androgen-deficient osteoporosis rat model. BMC Complementary Altern Med 2012;12:152.

18. Liu DD, Zhang JC, Yi CQ. The effects of gold nanoparticles on the proliferation, differentiation, and mineralization function of MC3T3-E1 cells in vitro. Chin Sci Bull 2010;11:1013-9.

19. Schroder HC, Kurz L, Muller WE, Lorenz B. Polyphosphate in bone. Biochemistry 2000;65:296-303.

20. Lynch M, Stein JL, Stein GS, Lian J. The influence of type I collagen on the development and maintenance of the osteoblastic phenotype in primary and passaged rat calvarial osteoblasts: modification of expression of genes supporting cell growth, adhesion and extracellular matrix mineralization. Exp Cell Res 1995;216:35-45.

21. Takeuchi Y, Nakayama K, Matsumoto T. Differentiation and cell surface expression of transforming growth factor-beta receptors are regulated by interaction with matrix collagen in murine osteoblastic cycles. J Biol Chem 1996;271:3938-44.

22. Wang W, Olson D, Liang G, Franceschi RT, Li C, Wang B, et al. Collagen XXIV (Col24 $\alpha 1$ ) promotes osteoblastic differentiation and mineralization through TGF- $\beta /$ Smads signaling pathway. Int J Biol Sci 2012;8:1310-22.

23. Shiga M, Kapila YL, Zhang Q, Hayami T, Kapila S. Ascorbic acid induces collagenase- 1 in human periodontal ligament cells but not in MC3T3-E1 osteoblast-like cells: potential association between collagenase expression and changes in alkaline phosphatase phenotype. J Bone Miner Res 2003;18:67-77.

24. Abiramasundari G, Sumalatha KR, Sreepriya M. Effects of Tinospora cordifolia (menispermaceae) on the proliferation, osteogenic differentiation and mineralization of osteoblast model systems in vitro. J Ethnopharmacol 2012;141:474-80.

25. Jaquiéry C, Schaeren S, Farhadi J, Mainil-Varlet P, Kunz $\mathrm{C}$, Zeilhofer $\mathrm{HF}$, et al. In vitro osteogenic differentiation and in vivo bone-forming capacity of human isogenic jaw periosteal cells and bone marrow stromal cells. Ann Surg 2005;242:859-67.

26. Hoemann CD, El-Gabalawy H, McKee MD. In vitro osteogenesis assays: Influence of the primary cell source on alkaline phosphatase activity and mineralization. Pathologic Biologie 2009;57:318-23.

\section{How to cite this article}

- Hnin EI Thu, Isa Naina Mohamed, Zahid Hussain, Norazlina Mohamed, Ahmad Nazrun Shuid. Eurycoma longifolia, a malaysian medicinal herb, significantly upregulates proliferation and differentiation in pre-osteoblasts (MC3T3-E1): an in vitro model. Int J Pharm Pharm Sci 2016;8(11):199-204. 